\title{
Práticas políticas de Antigo Regime: redes governativas e centralidade régia na capitania de Minas Gerais (1720-1725)
}

\author{
Claudia Cristina Azeredo Atallah
}

\section{Introdução}

A importância do estudo das redes para a tentativa de interpretação do universo político do Antigo Regime português é incontestável. A diversidade das relaçôes sociais que pairava sobre o campo dos poderes, pela insuficiência do direito oficial da época, conferia legitimidade a práticas políticas consideradas, a primeira vista, informais. Desse modo, como nos advertem António Manuel Hespanha e Ângela Barreto Xavier, as relaçôes do tipo clientelar sustentavam uma interdependência e reciprocidade que garantiam as intenções sociais e políticas individuais. $\mathrm{O}$ protagonismo político daqueles homens estava intimamente relacionado a tais aspectos. ${ }^{1}$

Assim sendo, os oficiais régios que compunham a administração periférica estavam atrelados entre si, a compromissos e a uma teia de reciprocidades que envolvia inclusive a Coroa e que desenhava a dinâmica política de então.

Dentro desse contexto de análise, a historiadora Maria de Fátima Gouvêa desenvolveu o conceito de redes governativas. Os vínculos estratégicos estabelecidos entre "um grupo de oficiais régios" fundavam nexos entre as diferentes partes do império, por intermédio de indivíduos que compartilhavam entre si laços de parentesco e interesses políticos e econômicos. Propóe-se aqui estudar alguns conflitos estabelecidos na Comarca do Rio das Velhas, capitania de Minas Gerais sob a ótica do estudo das redes governativas. A análise desses conflitos cotidianos, travados entre o governador Dom Lourenço de Almeida e o ouvidor da Comarca, José de Souza Valdes, retrata muito bem as articulações desses homens e dos grupos aos quais pertenciam, além de demarcar o papel de centralidade da Coroa portuguesa como "o elemento essencial de equilíbrio e funcionamento de todo o complexo governativo imperial”.

O governo de D. Lourenço de Almeida nas Minas foi marcado profundamente por conflitos travados cotidianamente, sejam por direitos que os povos acreditavam ter, dentro do universo normativo do Antigo Regime português, ou por jurisdiçôes, entre os homens da governança real.

Embora o período em que esteve no poder seja extenso, aqui contemplaremos os quatro primeiros anos (1721-1725). Época em que iria travar verdadeiros combates por jurisdição com o ouvidor da comarca do Rio das Velhas, José de Souza Valdes.

José de Souza Valdes fora nomeado para ouvidor da Comarca do Rio das Velhas, na capitania de Minas Gerais por provisão de 18 de março de 1720, sendo o terceiro ouvidor da dita Comarca. ${ }^{2}$ Em 18 de agosto de 1721, tomava posse do governo da capitania de Minas Gerais Dom Lourenço de Almeida. Em Vila Rica, na "Igreja Matris de Nossa Sr. a do Pilar de Ouro Preto em presença dos oficiais da Câmara da mesma vila deu posse deste governo das Minas o Governador atual delas o Ex. Sr. Conde de Assumar Dom Pedro de Almeida (...)" ${ }^{3}$

Em setembro de 1721, D. Lourenço escreve ao rei relatando as inconveniências provenientes da tentativa de se estabelecer o contrato de corte de carnes em Vila Real. Para isso, acusava a câmara e o ouvidor geral daquela comarca (José de Souza Valdes) de buscarem favorecimento, alegando que "estes contratos das carnes no Brasil sejam sumamente odiosos e prejudiciais aos povos porque sempre redundam em interesses [sic] particulares". Ainda relata a dificuldade em se controlar os moradores do Sabará, afirmando que "fizeram aqueles moradores um princípio de motim pouco antes da minha chegada, e 
para se aquietarem foi necessário desvanecer-se inteiramente o dito contrato". Desse modo, associa as desordens que se operaram na região ao desejo dos oficiais em beneficiarem "suas conveniências particulares", posto que tais contratos "podem ser causa de motins que sejam dificultosos de sossegar (...)". ${ }^{4}$

A partir da análise desse episódio, fica clara a existência de uma frágil fronteira que demarcava as relações de poder entre as autoridades em todo esse universo. Nesse caso, nas Minas, os inconvenientes giravam em torno do governador, do ouvidor José de Sousa Valdes e do Senado da Câmara de Sabará, ainda mais se tratando de assunto tão delicado quanto ao abastecimento da região. D. Lourenço ainda cita outro incidente parecido, que havia ocorrido na Vila de São João Del-Rey, onde se intentou estabelecer o contrato "das águas ardentes da terra", gerando outra ameaça de motim, suscitando também que a culpa pela desordem seria da Câmara. ${ }^{5}$

Por termo firmado em Junta "na Vila do Ribeirão do Carmo" a três de fevereiro de 1715 ficou resolvido que as Câmaras teriam o direito sobre "as cargas que entrassem para as Minas". Por tal direito deveriam repassar à Coroa trinta arrobas de ouro, divididas da seguinte forma: "de cada carga de fazenda seca, oitava e meia de ouro; de cada carga de molhados, meia oitava; de cada cabeça de boi ou vaca, uma oitava." Em 23 de julho de 1716, por termo da Junta em Vila Rica o primeiro era alterado: aumentava-se o valor de cada cabeça de gado e instituía-se "de cada escravo ou escrava que entrasse a primeira vez em Minas" o pagamento de duas oitavas. Foi o Conde de Assumar que "fez novo ajuste com os povos" na Vila de Ribeirão do Carmo em três de março de 1718. Dessa vez "se obrigaram a pagar vinte e cinco arrobas de ouro em satisfação dos quintos, ficando livre para Sua Majestade o direito das cargas (...)" ${ }^{6}$

Contratos de entradas e passagens serviam para que autoridades locais controlassem o fluxo comercial tão intenso na região. A questão do fornecimento da capitania sempre gerou incertezas e preocupações por parte das autoridades. Ao mesmo tempo em que a população carecia do controle dos preços e da distribuição (e a ineficácia disso gerava o perigo constante de motins), alguns poderosos envolviam-se com o monopólio desses produtos, objetivando os lucros que advinham daí.

Segundo Júnia Furtado, a carência de produtos alimentícios "desorganizava o mundo urbano e punha em risco a estabilidade social". Com relação ao comércio das carnes, "a principal fonte de impostos”, a possibilidade de sua escassez já causava temor por parte das autoridades. A historiadora aproveita para ressaltar a importância das câmaras da capitania na gestão desses assuntos. A tarefa de regulamentar e controlar os mercados locais estava nas mãos desses organismos e, a partir do aumento de seu protagonismo político e social, foi possível observar o crescimento "de uma infraestrutura burocrática". Mesmo com toda influência que as câmaras foram capazes de exercer sobre essa sociedade, "era sempre difícil exercer um controle severo sobre o abastecimento urbano". E, como agravante dos conflitos, temos de considerar a importância da região para o corte da carne bovina. Como já afirmou Adriana Romeiro, "o gado que se cortava nas minas era proveniente, em sua maioria, dos currais" do rio São Francisco, e isso estava relacionado às redes comerciais e mercantis que se estabeleceram ao longo dos caminhos que interligavam a capitania à Bahia. A maioria dessas redes ia "dar no arraial do Sabará, a porta de entrada para as minas" e ainda passavam pelo vale do rio das Velhas, "onde havia fazendas destinadas à engorda dos animais". ?

Como podemos notar as associações entre os oficiais e mesmo com alguns produtores locais influenciariam diretamente na gestão dos favorecimentos no arremate de tão precioso contrato, principalmente numa região que possuía como vocação, além da extração aurífera, o trato com o gado.

Passados alguns dias, D. Lourenço escrevia ao rei informando-o sobre a arrematação das passagens do Rio das Velhas feitas pelo ouvidor José de Souza Valdes, "o que fez sem contradição alguma”. Isso somente corrobora a grande complexidade que envolvia a questão do abastecimento e do controle dos seus rendimentos pelas autoridades locais. Tal questão está relacionada à instabilidade social e econômica: o medo de motins por causa de crises no abastecimento era constante, o que levou as autoridades a se posicionar quase sempre a favor do bem-estar dos povos, controlando de perto a arrematação dos contratos; assim "a fiscalização mais severa estava reservada ao comércio de carne verde". Por outro lado, "as 
avultadas quantias auferidas pelas câmaras e pela Fazenda Real quando da arrematação dos contratos" chamava a atenção, levando os próprios oficiais régios a se envolver com os ditos lucros. "O mercado interno de gêneros alimentícios nas Minas Gerais do século XVIII funcionava de acordo com as regras da oferta e da procura" e, tanto governadores, oficiais das câmaras, ouvidores, "quanto tropeiros, marchantes de gado, comissários de mantimentos, atravessadores e roceiros tinham consciência disso". ${ }^{8}$

Em março de 1721, D. João V enviava uma carta a D. Lourenço relativa às denúncias de abusos por parte dos oficiais da justiça:

(...) os oficiais da Câmara da Vila do Carmo e outras pessoas zelosas do bem público me representaram que os ministros e oficiais da justiça e fazenda que me servem nas minas gerais levam tão exorbitantes salários pelas assinaturas, escritas e diligências que se fazem intoleráveis aos povos; e porque convem remediar este dano, vos ordeno que logo que tomares posse do governo mandeis chamar perante vós dois ouvidores dos que tiverem acabado os seus lugares e com eles fareis uma pauta na qual se trazem os salários proporcionados ao citado da terra e de sorte que nem os povos sintam o (...) que até agora o experimentaram, nem os Ministros e oficiais fiquem sem os emolumentos necessários para a sua sobrevivência e de tudo o que obrarem nesta mesma me dareis conta com a mesma pauta para haver de a confirmar, ou reformar como foi servido: porém o que ajustarem com os ditos Ouvidores fareis logo executar provisoriamente para que se observe, enquanto eu não mandar o contrário (...). ${ }^{9}$

Os supostos abusos dos oficiais da justiça eram denunciados por importantes representantes do poder local: os oficiais das câmaras. O monarca, dentro da dinâmica política do Antigo Regime, em que a justiça era o equivalente máximo do bom governo, recomendava ao governador que então tomava posse, que ponderasse nesse caso; que coibisse tais abusos em nome do bem público e, por outro lado, cuidasse para que os oficiais não ficassem sem condições de sobrevivência nas distantes Minas Gerais. Seria interessante atentar para a questão do bem público, aqui, nos parece, intimamente relacionado com a justiça do bom governo. A consciência de que os rendimentos reais faziam parte do montante que representava um bem inerente ao público tornaria maior a responsabilidade do lidar com tais rendimentos nos distantes domínios coloniais. Nesse sentido, para que não houvesse leviandade, o rei recomendava ponderação e a aplicação da justiça, reconhecendo também as diversas faces do poder.

A essa carta D. Lourenço respondia no dia 12 de abril do ano seguinte, informando que já havia preparado um novo regimento para os emolumentos dos ouvidores. Tecia, oportunamente, algumas reclamações acerca do ouvidor do Rio das Velhas. Informava-o que agiu "na forma que Vossa Majestade foi servido mandar-me" e que já havia mandado "observar em todas as Comarcas a mesma forma que Vossa majestade (...) ordenou”. Mais à frente relata:

Este regimento se tem observado com geral aceitação dos povos, e os ministros a todos o fazem observar inviolavelmente, exceto o Dr. José de Sousa Valdes, Ouvidor Geral do Sabará, o qual fez caso do regimento e leva de salários e consente que os seus oficiais levam cada qual o que quer. ${ }^{10}$

Portanto, faz uma acusação clara de descumprimento da ordem real, informando ao rei que Valdes seria o único oficial que não havia acatado o regimento. Acrescentava ainda que o ouvidor consentia que seus subordinados "levassem mais do conteúdo em seu Regimento". ${ }^{11}$

O governador informava que dava "esta conta a Vossa Majestade para que determine o que for servido, da forma que seus vassalos do Sabará não padeçam mais esta violência”. Segundo D. Lourenço, o ouvidor dizia não estar subordinado a ele (e para essa afirmação cita o capitulo sete de seu regimento), "e não só o diz senão o mostra, não obedecendo as ordens que lhe mando (...)". Ainda transcreve sobre algumas outras violências cometidas pelo dito ouvidor contra "os povos" das Minas Gerais, declarando que o fazia por se considerar "tão sumamente isento da minha jurisdição". Para isso pede ajuda:

...e como Vossa Majestade não me dá jurisdição para evitar estas violências que fazem estes Ministros e eles me não obedecem porque dizem que não [são] súditos dos Governadores, dou esta conta a Vossa Majestade 
pedindo que me queira fazer a mercê de me ordenar o como me hei de haver com eles nestas matérias que são fora da jurisdição ordinária... ${ }^{12}$

Esse fato suscita mais uma vez nesse trabalho a discussão acerca do caráter jurisdicional da cultura política do Antigo Regime em Portugal. Tais características não estariam somente presentes nos regimentos e estatutos que regiam toda a administração política, mas, sobretudo, nas práticas políticas cotidianas desses homens. Os espaços de poder se chocavam e, mesmo que isso viesse a dificultar pretensões de superioridade, recorriam ao centro de onde emanavam seus poderes: a figura do monarca. Tanto na rejeição de autoridades similares ou ainda na busca por orientaçôes, a Coroa agiria sempre como árbitro e expressava, desse modo, a centralidade régia. ${ }^{13}$

Em maio de 1722, D. João V recomendava ao governador que ouvisse "aos oficiais das Câmaras desse governo sobre o que contem o dito regimento" que remetesse a ele "as suas respostas para se tomar a resolução que for conveniente". D. Lourenço havia cumprido sua ordem de convocar dois ex-ouvidores para a elaboração do dito regimento, a saber: Bernardo Pereira de Gusmão, ex-ouvidor da Comarca do Rio das Velhas e Manoel Luis Cordeiro, ex-juiz de fora do Rio de Janeiro. Mesmo assim, o monarca esperava o aval dos oficiais camarários, recomendando que "se pratique provisoriamente o regimento (...), fazendo observar pontualmente" ${ }^{14}$ Quanto aos abusos de José de Souza Valdes, não fez referência.

Com tais recomendações, $\mathrm{D}$. João $\mathrm{V}$ reconhecia francamente o poder que as câmaras de vereadores detinham no universo político local das Minas Gerais (não só). Tinha conhecimento da independência político-administrativa e da popularidade que tal instituição adquirira com o passar do tempo. Esses homens mantinham uma via de correspondência direta com o Reino, sem "se ater aos Capitães Generais, Vice-Reis ou outras autoridades intermediárias" e por isso eram respeitados por esses oficiais régios. ${ }^{15}$

A esse respeito, interessante citar uma carta enviada ao monarca pelo governador das Minas em outubro de 1722. Ele relata que José de Souza Valdes havia passado "ao sítio do Papagaio a formar uma vila”, por ordem do Conde de Assumar. No entanto, segundo sua opinião, aquele arraial não possuía estrutura para se tornar uma vila e ainda afirmava "que pela experiência que tenho dos povos destas minas" não achava conveniente

ao real serviço de Vossa Majestade que se crie de novo mais vilas". A razão de suas afirmações residia no fato de que "todos esses povos enquanto são arraiais vivem sossegadamente, por não terem ambição de entrarem nas governanças, por que em sendo vilas logo se formam parcialidades sobre quem há de ser juiz e vereadores e o pior é que tomando o pretexto do bem comum não querem consentir nada que seja em conveniência do serviço de Vossa Majestade e aumento de sua Real fazenda. ${ }^{16}$

Pelo que nos parece, o papel político, além do administrativo, das instituições camarárias estava bastante claro para esses representantes do poder real. As atribuiçôes que lhes eram conferidas, gerando a autonomia política, demarcavam os espaços de poder que não poderiam ser subtraídos. Restava, desse modo, impedir a criação de novas vilas.

Os excessos na cobrança dos emolumentos era questão de difícil resolução. Em 23 de dezembro de 1723 D. João V ordenava, por decreto, que D. Lourenço, "pela parte que vos toca", evitasse "que os escrivães das mesas dos despachos e oficiais de justiça de Fazenda lev[em] as partes emolumentos excessivos contra o Regimento". Recomendava também que fossem "castigados esses oficiais, com o rigor da lei", para que não continuassem "as queixas". ${ }^{17}$

A respeito das relações entre o ouvidor e a câmara de Sabará, tal aspecto, além de ser estatutário, posto que reconhecido pelas Ordenações, também possuía nuances de parcialidade. $\mathrm{O}$ ouvidor, como consta nas próprias leis do Reino, estabelecia fortes vínculos com o poder local. Isso era possível a partir do poder de fiscalização que lhe fora conferido, fazendo com que laços de clientela fossem atados entre ambos. Dom Lourenço de Almeida parecia estar ciente de tal fato. Em cinco de dezembro de 1721, escrevia a José de Souza Valdes informando que se achava "sumamente queixoso dessa Câmara por ser a 
única destas Minas que não quer pagar 150 oitavas de ouro que o seu procurador prometeu para pagamento dos Oficiais da Casa da Moeda". ${ }^{18}$ Como se vê, a instalação da casa de fundição e moeda ainda causava mal-estar. Segundo Teixeira Coelho,

os procuradores das Câmaras fizeram protestos da sua fidelidade, dizendo que estavam prontos para a observância das leis como vassalos fiéis; porém, que, como as ditas Casas tinham causado horror ao povo espalhado pelas habitações dos matos e faltos do discernimento preciso para conhecer os interesses que the podiam resultar do estabelecimento indicado, poderia alterar-se novamente e que, para se evitarem outras desordens semelhantes às que tinham sucedido no governo passado, ofereciam a Sua Majestade mais doze arrobas de ouro em cada um ano para satisfação dos quintos, (...) e que por esse meio ficava a Real Fazenda utilizada e os habitantes de Minas em sossego. ${ }^{19}$

Portanto, quanto ao assunto das Casas de Fundição e Moeda, o tom era sempre de negociação, haja vista o conflito que se estabelecera anos antes em Vila Rica. ${ }^{20} \mathrm{O}$ que não se pode negar é a necessidade de participação do poder local por meio das câmaras. D. Lourenço ameaçava prender os oficiais camarários caso não remetessem logo o ouro devido e solicitava ao ouvidor que o livrasse "de fazer este mal a estes homens", que os chame "e os persuade e os obriguem a fazerem esta remessa por que assim fico eu descansado e eles também." É possível observarmos que o governador tinha ciência das amarrações que prendiam o ministro da justiça aos camarários, exigindo sua persuasão para a remessa da dita dívida. Vale a pena citar que o governador enviara, um dia antes, uma carta com o mesmo conteúdo "para os oficiais da Câmara de Vila Rica”. ${ }^{21}$

As relações entre o governador e o ouvidor só tendiam a piorar. Em carta de 14 de abril de 1722, D. Lourenço de Almeida dá notícias ao monarca da prestação de contas da Real Fazenda. Relata que o "Superintendente Geral Eugênio Freire de Andrada, em virtude das reais ordens de Vossa Majestade tem tomado algumas contas (...) e vai continuando em tomar as que faltam". Aproveita ainda para elogiar os serviços do superintendente e do "Tesoureiro dos Defuntos e Ausentes da Comarca do Rio das Velhas, Manoel Gonçalves Loures, ao qual alcançou em uma grande soma de ouro" contra os abusos dos provedores. Ainda afirma sobre Loures:

...e como sei que ele dá conta a Vossa Majestade com toda exação e com toda aquela verdade com que costuma falar, por que verdadeiramente é um Ministro de Vossa Majestade de grande suposição, a dita conta que ele der a Vossa Majestade me remeto por que a conferiu comigo. ${ }^{22}$

O governador deixa transparecer as amarrações que prendiam suas redes nas Minas. Enquanto tecia elogios aos dois oficiais, procurava comprometer José de Sousa Valdes. Afirmava que

o dito Eugênio Freire de Andrada também dará conta a Vossa Majestade de todas quantas dúvidas teve com o ouvidor do Sabará, José de Sousa Valdes sobre esta mesma conta do Tesoureiro dos Defuntos e Ausentes da mesma Comarca (...) por que eu, da parte de Vossa Majestade, lhe ordenei que de todo o sucedido com o dito Ministro desse conta, dizendo a vossa Majestade a grande repugnância que esse Ministro tinha em me obedecer as ordens que eu lhe dava (...) e como este Ministro por carta que tenho suas me diz que não estava a minha ordem para me obedecer, nem como Provedor dos Defuntos e Ausentes nem como Ouvidor, por que estas duas jurisdições são isentas das dos Governadores e assim não dava a execução as ordens que eu lhe mandava. ${ }^{23}$

Ao mesmo tempo em que se aliavam e se resguardavam no Reino, esses homens faziam valer as mesmas alianças nas distantes possessões ultramarinas. Buscavam desse modo associações locais que pudessem lhes garantir domínio territorial e (ou) político e colaborando para tecer a imensa teia de reciprocidades que costurava todo o império.

Como já citado na introdução, Maria de Fátima Gouvêa desenvolveu uma discussão acerca do conceito de redes governativas: 
...uma rede é compreendida enquanto um conjunto de conexões recorrentes, capaz de alterar ou definir estratégias, bem como o curso dos acontecimentos num dado lugar e época. (...), é possível propor uma noção de rede governativa entendida enquanto uma articulação estratégica de indivíduos, como um núcleo de indivíduos articulados de modo mais estável, contando com presença de outros de forma mais inconstante. Essa articulação era resultado, em grande parte, da combinação das trajetórias administrativas dos indivíduos conectados pelo meio da rede e das jurisdições estabelecidas pelos regimentos dos cargos que os mesmos iam progressivamente ocupando. Prescrições essas que instituíam determinados padrões de recrutamento e de remuneração no âmbito da administração no império português. ${ }^{24}$

Considerando as práticas de governação por todo o império, a historiadora enfatizou a ideia de que o ato de governar ia muito mais além que as relações políticas institucionais. Do mesmo modo, a ação das redes governativas incidia diretamente sobre a organização política, no exercício cotidiano do poder no Reino e em seus domínios. Definia, assim, "os vínculos estratégicos entre oficiais régios". ${ }^{25}$

E eram esses mesmos vínculos que D. Lourenço procurava manter. Justificava assim a convocação da Junta da Fazenda, "composta do Dr. Provedor da Fazenda Real, o Dr. Procurador dela e Coroa e do mesmo Eugênio Freire”, para que pudesse obrigar José de Sousa Valdes a cumprir as ordens. Ainda assim, segundo o governador, o ouvidor se recusou a acatá-las, "chamando a esta Junta da Fazenda Tribunal intruso", em carta dirigida a ele. Reclamava mais uma vez da falta de jurisdição sobre o ouvidor, pedindo ao monarca que lhe instruísse "como me hei de haver com os ouvidores que não me obedecerem (...)" ${ }^{26}$

No dia seguinte, escrevia outra carta ao Reino explicando que logo "assim como partiu a frota do Rio de Janeiro para essa Corte" havia mandado as câmaras cobrarem "os Reais Quintos de Vossa Majestade que se lhe deviam de um ano". Informava também que daria início à cobrança dos quintos do ano corrente, "para que, sem falta, vão os quintos destes dois anos a vossa Majestade por esta frota que vier ao Rio de Janeiro, que importarão trinta arrobas de ouro que se devia e quarenta arrobas desse ano em que já governo esta conquista." Aproveitara para fazer mais queixas contra o ouvidor da Comarca do Rio das Velhas, acusando-o inclusive de intentar "alguma revolução que parece desejava", incitando "os povos" a não pagarem os impostos devidos. Explicava, contudo, que os oficiais da câmara, como "bons vassalos de Vossa Majestade", não haviam aderido às incitaçôes. Aproveitava para pleitear, novamente, "mais jurisdição nestas Minas", explicando que, se a tivesse, "o mandaria prender para o remeter a essa Corte".

Como podemos notar, o assunto da cobrança dos quintos tornava as relações do poder local bastante instáveis. Desde a descoberta das minas, tal questão era notória e o auge dos conflitos, até então, havia sido a Revolta de Vila Rica e seus desdobramentos. D. Lourenço de Almeida recebeu da Coroa ampla autonomia para instaurar a cobrança como lhe conviesse, "podendo mesmo voltar ao método da finta, com tanto que a soma apurada para a Fazenda Real fosse superior às antigas trinta arrobas". $\mathrm{O}$ fato é que, até o estabelecimento das Casas de Fundição e da Casa da Moeda, em 1724, o governador conseguira aumentar consideravelmente a arrecadação. ${ }^{27}$

Em carta de 28 de outubro de 1722, o governador enviava ao Reino a "certidão tirada dos livros da Fazenda" comprovando "o acréscimo que vossa Majestade tem tido na sua Real Fazenda, depois que governo estas minas". Tão satisfatória vinha sendo a arrecadação que, em 1725, já com o funcionamento das Casas de Fundição, D. João V agradecia "ao Governador o bem que se houve na cobrança dos quintos", declarando "que se viu o que relatais e que se vos aprova e louva a providência que tivestes na cobrança dos quintos". ${ }^{28}$

As contendas entre o governador e o ouvidor pareciam atingir seu ápice. No mesmo dia da carta citada acima, D. Lourenço dava conta da criação dos ofícios de Juízes dos Órfãos para Vila Real do Sabará e para Vila Nova da Rainha, "como Vossa Majestade manda pela sua lei que em todas as Vilas e seus termos que passarem de quatrocentos vizinhos". Os cargos haviam sido criados para, respectivamente, Manoel de Mendonça e Lima e Manoel de Afonseca Pereira. Amparado pelas leis régias dessa vez denunciava que Valdes, "sem fundamento algum", posicionara-se contra a nomeação relativa à Comarca do Sabará. Acusava o ouvidor "de ter passado algumas provisões de serventias de ofícios", interferindo 
em sua jurisdição, quando "Vossa Majestade, pelo seu regimento, manda que, os seus Governadores passem as provisões de serventia de todos os ofícios que não tiverem proprietários". E, como os apelos pela jurisdição ampliada não estavam surtindo efeito, dessa vez pedia ao monarca que "me queira fazer a mercê de mandar que este Ministro se abstenha de se intrometer na minha jurisdição". ${ }^{29}$

A essa carta, D. João respondia, em 1725, ordenando ao governador que suspendesse tão logo a nomeação para o dito cargo da Vila Nova da Rainha e que "sirva de Juiz dos Órfãos o Juiz Ordinário, enquanto eu não mandar o contrário". Sobre seus sucessos com o ouvidor de Sabará, o monarca, mais uma vez, não fazia referência... ${ }^{30}$

Conflitos por jurisdição expressavam muito bem o pluralismo político do Antigo Regime e não interferiam na centralidade régia. Esses homens recebiam da Coroa, via regimentos, "delegação de autoridades e de poderes" que os tornavam representantes do poder real. Tal estratégia, ao contrário de aniquilar o poder real, tornava-o possível nas distantes paragens coloniais da América:

era a Coroa o elemento essencial de equilíbrio e funcionamento de todo o complexo governativo imperial, reconhecendo e confirmando lugares diferenciados na hierarquia social da época. Era a Coroa quem tinha recursos e meios para garantir o equilíbrio de um modo de governar. Aí residia a centralidade da Coroa, encontrando na pessoa real o ponto essencial de ordenação do conjunto social. ${ }^{31}$

Portanto, ao escrever ao monarca a respeito desses conflitos, os oficiais régios somente vinham a corroborar a dinâmica de centralidade régia. A necessidade do reconhecimento da monarquia das atitudes em prol do bem-estar público e dos conflitos animava a lógica da remuneração dos serviços prestados, "o que referenda ainda mais a centralidade da Coroa no cotidiano da sociedade colonial". ${ }^{32}$ Nesse caso, ao monarca interessava mais manter tais conflitos em aberto do que se posicionar a favor de um oficial. E isso implicava também institucionalizar a negociação em vez da punição.

Voltemos ao caso do Tesoureiro dos Defuntos e Ausentes. Em 15 de novembro de 1722, D. Lourenço de Almeida relata um incidente ocorrido na Comarca do Rio das Velhas. O caso envolvia a prisão do "tesoureiro que foi dos Defuntos e Ausentes" Manoel Gonçalves Loures. O sobredito estava sendo acusado por José de Souza Valdes de desvios na prestação à Coroa dos rendimentos do Juízo do qual outrora fora responsável. O governador informava que "por ordem de vossa Majestade", Eugênio Freire de Andrade havia tomado conta das prestaçôes do ex-tesoureiro "e se achou alcançada em trinta e duas mil oitavas de ouro". Ao mesmo tempo, Valdes, "lhe estava tomando a mesma conta por ordem de Vossa Majestade, expedida pela Mesa de Consciência e Ordens, e lhe havia achado maior alcance". Como podemos observar, a situação do governador poderia se tornar delicada, pois em carta anterior ele declarava ao monarca que tinha aprovado as contas que dera Loures à Real Fazenda. Nessa, porém, foi mais prudente, informando que as contas haviam sido tomadas por Eugênio Freire de Andrada, "por ordem de Vossa Majestade". ${ }^{33}$

Eugênio Freire de Andrade havia sido nomeado para o importante cargo de Superintendente das Casas de Fundição de Minas por carta régia de 11 de maio de 1719. Com jurisdição bem alargada, o cargo possuía "sua alçada judicial para a solução de pendências entre mineradores e a aplicação de penas aos contrabandistas e aos que de alguma forma lesassem o fisco." ${ }^{34}$ Colaborava, na verdade, para as indefinições jurisdicionais que pairavam sobre os ministros régios.

Desse modo, ao constatar tal diferença, o ouvidor havia mandado prender o antigo tesoureiro. Iniciava-se, a partir daí, uma verdadeira batalha jurisdicional entre o governador e o ouvidor, ao mesmo tempo em que lutariam para preservar as amarraçōes de suas redes e as consequentes repercussões no Reino. O caso vinha se arrastando, segundo a documentação, há pelo menos um ano. Ao constatar que Valdes havia mandado prender o tesoureiro, D. Lourenço inicia uma longa empreitada no sentido de convencer o ouvidor a remeter o preso a Vila Rica. Em carta de 23 de dezembro de 1721 oferece, para o translado do acusado, "toda a segurança" e "também para a sua guarda os soldados Dragóes que V. M. me disser são necessários". ${ }^{35}$ 
A essa carta, José de Souza Valdes respondia em janeiro do ano seguinte. Informava que, em sua opinião, "corre muito perigo a remessa do dito preso para a cadeia desta Vila, (...), principalmente com caminhos tão perigosos". Inversamente, solicitava que o "Superintendente que me poderá remeter todas as clarezas e papéis que forem precisos para a boa arrecadação". Portanto, a disputa para requerer para si a jurisdição sobre os crimes de Loures estava bastante clara. Na verdade, esses homens regozijam-se com a possibilidade de interferência na jurisdição alheia. Nesse caso, Valdes possuía a guarda do preso e, como tinha indícios de que D. Lourenço poderia estar envolvido nesses desvios, dificultava o acesso do governador e do superintendente reclamando a jurisdição sobre o caso. ${ }^{36}$

A resposta desinibida do ouvidor despertara o incômodo no governador e também no superintendente. D. Lourenço insistia, no dia sete do mesmo mês, no fornecimento de "boa guarda de soldados" para a transferência e no envio do "Sumário de testemunhas" que Valdes havia tirado "contra o tesoureiro Manoel Gonçalves Loures". Informava que tal documento era necessário "para a conta que lhe tem tomado" Eugênio Freire de Andrade. Dias depois, era a vez de este expressar sua indignação com a rebeldia do ouvidor. Representava ao governador ressaltando a falta de obediência do ouvidor. Para tal, instigava o general lembrando-o de que tinha "os poderes incorporados na sua patente de que todos os oficiais de Guerra, Justiça e Fazenda maiores e menores lhe obedeçam e cumpram as suas ordens com o que representa nesse governo a Real Pessoa de S. Maj.”. Informava também que não havia recorrido diretamente ao oficial da justiça de Sabará para "não me embaraçar com ele em pontos de jurisdição". ${ }^{37}$

A despeito do que Freire de Andrade dissera a respeito do poder do governador sobre o ouvidor, a grande dificuldade que os oficiais régios encontravam no mundo colonial para exercer poder de mando uns sobre os outros era notória, principalmente porque seus regimentos não estabeleciam esses limites. Considerando ainda o grande esforço de D. Lourenço em solicitar ao monarca maior espaço de jurisdição sobre José de Souza Valdes...

A Representação do superintendente levara o governador à outra tentativa, dessa vez mais incisiva, de transladar o preso de Sabará para Vila Rica e receber o sumário de testemunhas. Informava que sabia "muito bem que os Ministros, na ordem de administrar a justiça, são isentos de tudo por que são obrigados a sentenciarem conforme entenderem”. Porém, segundo ele, a isenção terminava

quando os Ministros obram de fato fazendo alguma violência aos povos por que neste caso com outros semelhantes estão subordinados aos governadores para lhe não consentir que façam exceção em prejuízo dos Vassalos de S. maj. por que os Governadores destas conquistas pelas ordens deles não só são Regedores da justiça senão também pelas mesmas Reais Ordens estar governando por El Rey e representando a Sua Real Pessoa (...) e seguro a V. M. que nem no meu Regimento nem na minha Patente achei ninguém excetuado da minha jurisdição. ${ }^{38}$

Dom Lourenço de Almeida citava seu regimento na tentativa de demonstrar que os governadores possuíam como dever zelar pelo bem-estar dos vassalos do rei. Os espaços de jurisdição desses homens, grosso modo, eram delimitados pelos seus regimentos, situação que dificulta um estudo mais geral. O que nos parece é que, desde a criação do cargo de ouvidor-geral, em 1548, e do estabelecimento do Tribunal da Relação na Bahia, o governador assistiu a uma redução de suas atribuições. Segundo Russel-Wood, "o século XVIII assistiu à emergência dos governadores das capitanias-gerais como forças dominantes na frente administrativa e política brasileira”. Esses oficiais "faziam nomeaçoes, emitiam títulos de sesmarias e exerciam a jurisdição administrativa sobre os assuntos internos. Contudo, mesmo com informações sobre suas atribuições, o fato é que se torna difícil esquadrinhar os limites de sua jurisdição". ${ }^{39}$

Destarte, mesmo considerando essas prerrogativas político-administrativas que, como sabemos, pouco valiam num império pluricontinental, acreditamos que os argumentos de Dom Lourenço de Almeida permeavam o discurso em torno do bem comum. O dever de zelar pelo bem público se constituiu, ao longo do Antigo Regime, um atributo político. Oficiais camarários e os agentes régios, como 
extensões legítimas do poder real, bem como o próprio monarca, possuíam a obrigação natural de assegurar o bem-estar social e político dos vassalos da República. ${ }^{40}$

Nesse sentido, nosso governador também recorre ao poder real para justificar suas atitudes e penetrar na jurisdição do ouvidor. Sobre os conflitos por espaços de poder travados entre Freire de Andrade e Valdes, recomendava a este que recorresse à Coroa para resolver as "matérias de jurisdiçôes a respeito de lhe mandar ou não o sumário por ser de matérias crime e eu me não meto nelas". A centralidade da Coroa estava aí explicita. ${ }^{41}$

A instabilidade política que havia pairado sobre a capitania era notória. E isso, segundo o governador, poderia causar "algumas desordens que eu receava sucedera em Vila Real". Ainda relacionava as ditas desordens e, por conseguinte a prisão, com "as grandes parcialidades que havia (...) causadas das imensas diferenças que havia entre o Ouvidor atual da dita Comarca (...) e Bernardo Pereira de Gusmão, seu antecessor". D. Lourenço explicava ainda que estava em Sabará naquele momento "por não faltar a obrigação que tenho de visitar os povos deste governo" e também para controlar as sobreditas desordens. ${ }^{42}$

Tais desordens foram mais além. O ex-ouvidor Bernardo Pereira Gusmão tentara de toda forma afiançar o preso, o que não conseguira. $\mathrm{O}$ governador ainda declarava que

...por haver notícia que o queriam tirar dela, todas as noites se fazia uma ronda à cadeia repartindo-se as noites, uma que rondava o Ouvidor José de Souza Valdes, outra o Capitão-Mor Lucas Ribeiro de Andrade, e outra o Coronel José Correa de Miranda, Juiz Ordinário da Vila... ${ }^{43}$

Assim, "como se viu a grande cautela com que estava guardado este preso, por ser tão considerável o alcance que devia à Fazenda dos Defuntos e Ausentes", Francisco Bernardo Loures, irmão do preso, intentara libertá-lo. O planejado deveria ocorrer na noite da ronda do ouvidor, que seria assassinado pelo dito Francisco "com outros do seu séquito". D. Lourenço afirmava que o sobredito teria conseguido o seu intento

se eu que me achava naquela Vila não fosse avisado na mesma noite, dando-se-me o ponto e aviso com toda a individuação, por cuja causa logo fiz a saber ao dito Ministro, mandando-lhe seis soldados que tinha de minha guarda e todos os meus oficiais que me acompanhavam, ordenando no mesmo tempo ao CapitãoMor da dita Vila, Lucas Ribeiro de Almeida, que puxasse por soldados da ordenança e fosse com eles para a casa do dito Ouvidor Geral, tomando com alguns as entradas e saídas da Vila para se prender todos cavaleiros que entrasse e saísse depois da meia-noite, por que a essa hora é que se queria fazer o insulto. ${ }^{44}$

O governador não declarava como obteve tantas informações detalhadas. O fato é que, ainda segundo a carta, Valdes "convocou muito mais gente daquela que era necessária" para a sua segurança (provavelmente não confiando na que o governador mandara) "e governou-se antes pelo que lhe pareceu mais acertado, do que pela ordem com que eu mandei fazer sentinela”. Relatava que pela madrugada entraram em Vila Real "quatro cavaleiros unidos" que logo foram abordados pelo Tenente dos Dragóes José de Morais Cabral, que os tentou prender, mas sem sucesso. Os ditos cavaleiros

trataram de se salvarem no mato fora da Vila, e com efeito indo fugindo e receando serem embaraçados por uns oficiais de justiça que estavam junto à ponte de um rio na saída da Vila, pela qual necessariamente haviam de passar, atiraram dois tiros aos ditos oficiais, e com uma bala cortaram o pulso a um meirinho e os mais companheiros com medo deixaram passar livres os ditos cavaleiros, que sem embargo de serem logo seguidos pelo Tenente José de Morais Cabral e soldados, não os puderam prender, favorecidos do grande escuro da noite e matos que há fora daquela Vila onde se embrenharam. ${ }^{45}$

Não podemos precisar se os cavaleiros haviam sido favorecidos somente pelo "escuro da noite" e pelos sertôes do Sabará. O fato é que D. Lourenço escrevia ao Reino dizendo que, logo na manhã seguinte, mandara expulsar de Vila Real do Sabará Bernardo de Gusmão, para evitar "mais alguma revolução", declarando que, com sua diligência até Vila Real, havia sossegado "sem estrondo toda a desor- 
dem que se podia seguir, fazendo com que depois desse sucesso, ninguém se atrevesse a insultar o respeito desse Ministro de vossa Majestade...”. ${ }^{46}$

Ainda recomendava ao monarca, "movido do zelo" com que o servia que era muito contra "o real serviço" que os ouvidores que acabassem seus lugares permanecessem nas comarcas que haviam servido. Segundo ele, "a experiência tem mostrado que da sua assistência nelas, resultam grandes desordens por causa das suas parcialidades". Para tal, dá o exemplo relatado e ainda o do ouvidor que fora de Vila Rica, Manoel Mosqueira da Rosa. Sugeria, por conta disso, que o Reino proibisse a esses ministros a compra de terras e lavras, e que, se comprassem, fossem confiscados "para a Real Fazenda de Vossa Majestade". A alegação era que com tais atitudes, a Coroa evitava que esses homens "se hão de dilatar nessas Minas (...) granjeando parcialidade para a conservação do respeito que sempre querem ter". Interessante analisarmos que, segundo as Ordenaçôes Filipinas:

Os Corregedores das Comarcas e Ouvidores (...) que forem postos em alguma Comarca Cidade ou Vila, ou em algum outro lugar e os juízes temporais e aqueles que pomos em algumas Cidades, ou Vilas, sem limitação de tempo certo, durante o tempo de seus Ofícios, não poderão fazer casas de novo, nem comprar, nem aforar, nem escaimbar, nem arrendar bens alguns de raiz, nem rendas algumas (...).

(...) E qualquer, que o contrário fizer, haja por pena, que o contrato seja nenhum; e tudo aquilo que por bem (...) receber, fizer ou houver, seja perdido e confiscado para nossa Coroa. ${ }^{47}$

Portanto, as recomendações e sugestóes que D. Lourenço fazia à Corte já constituíam penalidades...

Mais do que a observância estática das leis, tais vínculos eram fruto da dinâmica política cotidiana. Segundo António Manuel Hespanha, a "multiplicidade de jurisdiçôes" era a "origem de conflitos de competência". Isso se somava ao fato de que a Coroa não possuía como estratégia o caráter punitivo, concedendo espaços para as diversas interpretações do cotidiano. $\mathrm{O}$ aparelho de justiça também corroborava tal dinâmica, configurado que estava pelo "comunitarismo" do juízo local ou ainda pelo "corporativismo" dos "juristas letrados". Desse modo a efetiva aplicação da lei carecia "de eficiência" e, muitas vezes era suplantada pela concessão da graça real. ${ }^{48}$

Ocorrências como as citadas nos remetem mais uma vez à importância das redes locais que conservavam o status e o clientelismo entre esses homens. Mais ainda, garantiam relações de gratidão que poderiam garantir favores e futuras nomeações pelo império. Serviam também para manter os privilégios financeiros que haviam acumulado durante os anos que estiveram à frente de um cargo tão importante e com amplos poderes como era o de ouvidor dentro da dinâmica imperial portuguesa.

Bernardo Pereira Gusmão foi nomeado para o "ofício de Provedor das Fazendas de Defuntos e Ausentes Cappelas e Resíduos" da Comarca do Rio das Velhas por Provisão de vinte e cinco de fevereiro de 1717. O monarca ainda determinava que o bacharel houvesse "de servir no lugar de ouvidor do mesmo destino". Assim, Pereira Gusmão deixara o cargo em 1720 e até o incidente acima citado, habitava a Comarca na qual havia servido ao Reino. Vale a pena notar que, após todas essas informaçôes com tom de denúncia dadas por D. Lourenço de Almeida e com a sua expulsão da comarca em questão, foi nomeado "corregedor de Crime do Bairro de São Paulo por tempo de três anos (...)". Na provisão real, datada de dez de dezembro de 1726, o monarca relatava

...que havendo respeito ao bem que me tem servido o Bacharel Bernardo Pereira Gusmão nos Lugares de Letras que ocupou sendo o último o de ouvidor do Rio das Velhas de que deu boa residência e esperas de lhe que assim o fará daqui em diante em tudo o de que o encarregar... ${ }^{4}$

Como já citado, os conflitos que ocorriam por todo império não afetavam a centralidade régia e representavam as diversas faces do poder da política de Antigo Regime do império português. A concessão dos cargos era parte da dinâmica de interdependência que marcava as relações entre o monarca e seus súditos na manutenção da governabilidade. Todo esse aparato integrava "uma cadeia de poder e de redes de hierarquias que se estendiam desde o Reino" propiciando "vínculos estratégicos" com os vas- 
salos nas extensões coloniais. Portanto, mercês e privilégios retratavam a forma com que a monarquia "reforçava os vínculos de sujeição e o sentimento de pertença dos mesmos vassalos à estrutura política do Império (...)". E as práticas políticas desses homens eram parte de contexto. ${ }^{50}$

Em 17 de janeiro de 1747, D. João V concedia a aposentadoria a Bernardo Pereira Gusmão pelos serviços que "me fez nos seus lugares de Letras a sim na América e (...) nesta Corte (...) dando de todos boas residências". A despeito das denúncias de irregularidades apresentadas por Valdes anos antes, as ditas "boas residências" renderiam a Gusmão aposentadoria "em um lugar de desembargador da Relação do Porto", cidade para onde fora nomeado pouco tempo antes e que muitos que seguiam a carreira de Letras almejavam..$^{51}$

Voltemos para Sabará. No ano de 1723, o Conselho Ultramarino enviava um parecer, "pedindo ao ouvidor do Rio das Velhas que informe por que razão não procedeu contra os suplicados, dando por livres e isentos, sem para isso ter jurisdição". Os relatos eram sobre um conflito ocorrido em uma região da comarca sob seu Termo, Macaúbas. ${ }^{52}$

Em 12 de julho de 1724, José de Souza Valdes enviava uma carta ao Reino, onde parecia responder à citada consulta do Conselho Ultramarino. A carta, além do ocorrido, dava conta de algumas providências que deixara de tomar. $\mathrm{O}$ assunto girava em torno de um levante que havia ocorrido em Macaúbas no final de 1722, "por causa de um (...) potencioso que o governador D. Lourenço de Almeida deu em uma petição do Coronel José Corrêa de Miranda sobre uma sesmaria que diz que tem (...)". Acusava o governador de provocar inquietação na região e de querer expulsar algumas pessoas de suas terras, por ter passado a posse das referidas para o coronel José Correa de Miranda, Juiz Ordinário da Câmara de Sabará. Devido a isso, andavam "os ditos povos levantados com receios de serem presos", pois assim teriam sido ameaçados. ${ }^{53}$

Diante desse quadro, o ouvidor relata que o perigo crescera "por andarem bastantes dias levantados" e que precisou fazer "alguma diligência para o sossego deles". No decorrer de seus escritos procura todo o tempo culpar o governador, alegando inclusive que algumas pessoas tinham medo de ameaças feitas por ele e pelo sobredito coronel. Escrevia que o "povo" de Macaúbas nomeou "dois procuradores" que vieram a ele pedir providências perante o distúrbio que fora causado

pelo decreto do dito governador em querer tirar[-los] potenciosamente das suas posses e o dito coronel ameaçados que ia a buscar Dragóes as Minas Gerais para os prender ao que prudentemente os sosseguei e me requereram que lhes [dessem] o perdão em nome de V. Maj., o que fiz pela urgente necessidade em que me via e achando neles o justo motivo de suas queixas... ${ }^{54}$

Ainda informa que não pôde dar conta na frota de 1722 porque as pessoas que lhes passariam as certidões não haviam feito "com receio do dito governador". No intuito de se livrar da acusação de concessão de poder sem autorização real, o ouvidor atribuiria ao governador a culpa por ele ter de agir com tamanha prudência (e urgência). Agira em auxílio dos povos: dando o perdão real para que não se amotinassem, já que "passavam de quatrocentos homens de cavalo" e para que "não descessem a esta vila, pois já se dizia que o determinavam” a fazer.

Portanto, a consulta do Conselho Ultramarino pedia explicações quanto à concessão do perdão que Valdes havia dado sem ter jurisdição para tal. De acordo com o próprio caráter do poder da época e com bases na teoria corporativa de poder, a função mais nobre do rei era a de "fazer justiça". Segundo José Subtil, a justiça era potencializada por meio da "graça". Tal concessão não era competência da esfera jurídica, "nem comutativa nem distributiva", pois cabia ao arbítrio real. O monarca outorgava-a sob o juízo de sua própria consciência, dependendo fundamentalmente da "liberalidade régia". ${ }^{55}$ Desse modo, a despeito dos espaços de poder que os ouvidores possuíam na administração da matéria de justiça, a concessão da graça era um atributo real. O Conselho Ultramarino havia se manifestado, tendo em vista que o ouvidor em questão não possuía jurisdição (e nenhum outro) para conceder o perdão, um campo restrito à consciência real. ${ }^{56}$ 
A região de Macaúbas estava distante de Sabará "cinco léguas", localizada "na margem esquerda do Rio das Velhas". Infelizmente não encontramos a carta de sesmaria à qual o ouvidor se refere. No entanto, na Revista do Arquivo Público Mineiro encontramos uma referente ao ano de 1725 a respeito da mesma região. Dom Lourenço de Almeida concedia carta de sesmaria à ermida e recolhimento de Nossa Senhora da Conceição, no nome de Catarina de Jesus. Na referida carta, nos fornece indícios do quanto aquelas terras eram produtivas. Apesar de estarem "distantes das terras minerais", as requerentes "recolhidas" solicitavam toda a "distância precisa e necessária para criação do gado" que, segundo o governador, era para próprio sustento. A sesmaria era lavrada "sem prejuízo de terceiro, nem do direito que algumas pessoas possam ter as referidas terras ou pelas haverem ocupado ou por delas terem sesmarias ou outro título". Parece-nos, portanto, que a ameaça dos conflitos ocorridos anos antes ainda pairava sobre a região. ${ }^{57}$

"Fazendo correição em dezembro" do ano de 1723, José de Souza Valdes informava ao Reino algumas outras irregularidades do governo de D. Lourenço. Dava conta de que o Capitão-Mor José Botelho Fogaça ocupava também o cargo de Juiz dos Órfãos e neste estava "servindo muitos meses sem provimento (...) e nem deu fiança na Câmara na forma da Lei”. O ouvidor relatava ainda que "na obrigação de Juiz de Órfãos, o fez muito mal sem por em arrecadação os bens e ouro deles" e ainda denunciavalhe por outros delitos. ${ }^{58}$

Sua correição havia, portanto, resultado numa devassa que tirara a respeito dos crimes de Fogaça, confessando que "é tal a desgraça dessas alturas que tendo o dito Juiz de Órfãos na dita devassa culpas para o pronunciar, o não fiz e somente o suspendi”. Valdes justificava sua complacência com o acusado a partir das relações próximas que este nutria com o governador, que o tratava "com grande apresso de amizade". Ainda desenhava um emaranhado que amarrava os dois oficiais: Fogaça possuía relações comerciais com um cunhado de D. Lourenço; este, por sua vez, era padrinho de um irmão seu, Lourenzo Botelho Fogaça, que "serviu já de escrivão da Ouvidoria seis meses e estar com esperanças de o tornar a servir." Citava ainda o caso do ex-Tesoureiro dos Defuntos e Ausentes, Gonçalves Loures que, segundo ele, fugira quando D. Lourenço resolvera transferi-lo para o Rio de Janeiro. Insinuava que precisava ter prudência ao agir, explicando que "o temor do dito governador me fez faltar ao que devia e se outros menos poderosos me quiseram maquinar dissabores e tirar-me a vida melhor seria agora (...)” confiar no poder que o governador demonstrava. ${ }^{59}$

José de Souza Valdes fazia mais uma denúncia. Comunicava ao Reino que D. Lourenço de Almeida criara "aqui de novo o ofício de Juiz Executor da Fazenda Real e fez ao dito Capitão-Mor Juiz Executor". O ouvidor dizia "de novo" porque o monarca já havia tomado conhecimento de tal assunto tempos antes. Mais precisamente, numa carta de sete de maio de 1723 D. João V escrevia a D. Lourenço de Almeida

Faço a saber vós, D. Lourenço de Almeida, Governador e Capitão General das Minas que João Rodrigues Morteira, que vós o provereis no ofício de Solicitador da Fazenda Real na atenção de julgardes ser necessário o dito ofício para melhor arrecadação das dívidas da minha Real Fazenda e que pelo trabalho que havia de ter nesta incumbência lhe arbitrastes cem oitavas de ouro por ano, pedindo-me não só lhe confirmasse a provisão que lhe passastes, mas que se lhe desse ao menos duzentos mil reis de ordenado... ${ }^{60}$

O capitão João Rodrigues Morteira vinha solicitar ao rei a confirmação de sua nomeação, feita pelo governador das Minas, no cargo de Solicitador da Fazenda Real, pelo qual já havia o dito governador dado pagamento. Mais adiante, o rei diz que tem conhecimento que D. Lourenço havia criado mais um cargo, o de Executor da Fazenda Real "e outros oficiais mais" e exige imediatamente a extinção dos referidos cargos, já que "não cabia no vosso poder criardes semelhantes ofícios de novo sem primeiro me dares conta da necessidade que havia para os ditos provimentos". ${ }^{61}$

Mais adiante, provavelmente perante o grande constrangimento que causou a carta do rei, o governador a respondia em seis de junho de 1724, mais de um ano depois, explicando que encontrou a Real fazenda "mal administrada e muitas quantidades de dívidas perdidas", o que o levou a criar os cargos de 
Solicitador da Fazenda Real e o de Executor da Fazenda Real e "não outros como informaram a Vossa Majestade" por solicitação do Provedor da Fazenda e não por seu arbítrio. Atribui todo esse esforço aos desvios praticados pelos ouvidores que

faziam muito mal a sua obrigação pelo que toca a Real Fazenda de Vossa Majestade tanto assim que deixava de cobrar os devedores e só cuidavam em tomarem aposentadorias para si o que lhes fiz restituir (...) e também cuidavam em tirarem ajudas de custo por qualquer jornada que faziam a virem às Juntas, e tudo sem terem ordem de Vossa Majestade... ${ }^{2}$

Quanto ao cargo de Executor da Fazenda Real, para o qual tinha nomeado para a Comarca de Sabará José Botelho Fogaça, o governador relata que este "é homem muito honrado e zeloso do serviço de Vossa Majestade" e que fez "muitas cobranças de dívidas que os ouvidores que eram provedores deixaram perder" ${ }^{63}$

$\mathrm{Na}$ correição, o ouvidor informava que o governador insistira nas atitudes já repreendidas pelo monarca. José Botelho Fogaça assumia, portanto, três cargos ao mesmo tempo, e em dois dos quais não possuía as provisōes. O de Juiz de Órfãos, o de Capitão Mor e o cargo criado por D. Lourenço, o de Executor da Fazenda Real da Comarca de Sabará. Sobre estes dois, Valdes alertava ao Reino que era "contra o Regimento dos Capitães-Mores em que V. Maj. ordena que não sirva nenhum ofício de justiça nem da sua Real Fazenda...”. ${ }^{64}$

Tais denúncias que o ouvidor acreditava ter feito contra José Botelho Fogaça e, mais acertadamente contra D. Lourenço de Almeida, não atingiram o objetivo proposto. Ao menos não pelas vias legais, pois, em 14 de fevereiro de 1730, D. João V expedia outra nomeação de Capitão Mor em seu nome, devido

...ao dito José Botelho Fogaça haver servido na arrecadação da Fazenda Real no tempo que serviu o lugar de Provedor dos Registros dos Caminhos da Bahia e Pernambuco de que deu boa conta procedendo em todas as mais ocasiōes que ofereceram nas ditas Minas com grande fidelidade e zelo... ${ }^{65}$

Fogaça havia servido também nos Registros dos Caminhos do sertão, dando "boa conta" de seus ofícios, provavelmente após terminar o primeiro período como Capitão Mor, na mesma época das denúncias de Valdes. Essa segunda nomeação era para substituir o então falecido Capitão Lucas Ribeiro de Almeida, na qual "não haverá soldo algum da Fazenda, mas que consta de todas as honras, privilégios [e] liberdades (...) os que em 2 vezes dele lhe pertencerem". ${ }^{66}$

Mesmo que o domínio da Fazenda escapasse, grosso modo, das mãos desses homens comprometidos com a administração régia, sendo "a Fazenda gestão da casa de el-rei, fazia parte do seu domínio doméstico", a Coroa não poderia abrir mão da atuação desses homens na administração de seus domínios. E mesmo em uma área tão restrita quanto a Real Fazenda, havia espaço para o exercício das práticas políticas dentro da dinâmica corporativa em que se desenhava a monarquia portuguesa. Isso sem considerar os desvios e descaminhos que ocorriam quase sempre com a consciência (e às vezes participação) desses mesmos oficiais régios. ${ }^{67}$ Ao mesmo tempo, tal sociedade era pautada em distinçôes sociais e hierarquias que estavam representadas na importância desses cargos, mesmo que, por vias oficiais, não trouxessem a seus ocupantes rendimentos financeiros. Essas posições lhes conferiam status e privilégios nas sociedades de Antigo Regime e, como a mercê citada acima afirmara: "liberdades" para quem as possuía.

Em dezembro de 1724, o escrivão da Ouvidoria Geral de Correição de Vila Real do Sabará, Antônio Pereira Lopes, registrava em certidão algumas denúncias contra o ouvidor do Rio das Velhas. Tais denúncias vinham corroborar as já feitas por D. Lourenço tempos antes. Acusava-o de favorecer, desde que assumira o cargo, vários pretendentes aos contratos dos dízimos reais da referida comarca. Ainda relatava que desde então existiam várias irregularidades na arrematação e na cobrança dessas dívidas, excedendo Valdes a esfera de jurisdição do Provedor da Fazenda Real, Antônio Berquo Del Ryo. Segundo o escrivão, alguns dos beneficiados, como os capitães Sebastião Barbosa Prado e Ivan Ferreira dos Santos, pagavam os favores com "bens móveis e de raiz". 68 
Talvez como estratégia, no dia seis de abril de 1725, José de Souza Valdes dava mais conta ao Reino sobre os desassossegos em sua Comarca. Informava que, "por ordem de V. Maj.", havia tirado "devassa da fugida de Manuel Gonçalves Loures”. Informava também que o Capitão Mor que acompanhara Loures até o Rio de Janeiro, José de Souza Guimarães, estava devendo altas somas à Fazenda Real e que já havia enviado "ao Ouvidor do Rio de Janeiro um precatório para prender ao capitão". O dito ouvidor acatara o precatório e prendera o oficial, porém logo depois o soltou "com fianças". Na documentação, não fica muito claro o que foi feito dessa acusação; o que nos parece é que houve uma discordância sobre a jurisdição entre o ouvidor do Rio de Janeiro e José de Souza Valdes, da qual Souza Guimarães havia se beneficiado. O fato é que o sobredito Capitão Mor parece envolvido na fuga de Loures, pois acompanhava o preso até o Rio de Janeiro. ${ }^{69}$

Mais à frente, em outra carta, o ouvidor do Rio das Velhas relata um conflito ocorrido com o Provedor da Fazenda Real, António Berquó del Ryo. O caso girava em torno da cobrança de um precatório: ambos os oficiais reclamavam para si a jurisdição da cobrança da dívida. Não fica claro a quem pertencia a dívida citada por Valdes, não podemos precisar se é a mesma da carta anterior. O principal conteúdo desta é a sua reclamação quanto à jurisdição para a cobrança: acusava o Provedor de "querer arrecadar pela Fazenda Real o que não é dela, até os sequestros dos criminosos (...) que são devassa que dei conta a V. Maj. na frota passada (...) sumida por indústria de meu antecessor [Bernardo Pereira de Gusmão] para eu a não ver..." ${ }^{70}$

Para justificar suas alegações, Valdes citava as Ordenações Filipinas, mais precisamente "o tomo 12" do Livro Primeiro. Alegava assim que "V. Maj. mandou passar por leis que [os provedores] se não pudessem cobrar dívidas particulares" e que tal ordem "o trás citada o tomo 12". Na verdade, "o tomo 12" citado pelo ouvidor faz parte do Título 10 do Livro Primeiro, Dos Juizes dos feitos do Rei da Fazenda, que prevê que os Juízes da Fazenda

conhecerão de todos os feitos de injúrias feitas ou ditas aos Rendeiros de nossas rendas ou Oficiais delas, sobre a arrecadação de nossas rendas ou sobre seus Ofícios (...). Porém tratando-se os feitos sobre os ditos casos ante os Julgadores ordinários, as apelações que deles saírem irão aos Ouvidores dos feitos crimes e não aos Juízes de nossos feitos. ${ }^{71}$

Como se nota, esses oficiais possuíam conhecimento das leis do Reino e as citavam sempre que pretendiam defender seus espaços de jurisdição. Assim o fez Berquó Del Ryo devido ao mesmo conflito, como notamos acima.

José de Souza Valdes ainda pedia ao monarca para "dar a providência que achar servido e declarar ao Governador e Provedor que não te[nham] jurisdição sobre os ouvidores". ${ }^{72}$

Em 18 de abril de 1725 o Conselho Ultramarino respondia as dúvidas do ouvidor relativas às cobranças do precatório, porém não era muito esclarecedor. Pedia informações sobre as ditas dívidas e melhor esclarecimento ao "Concelho da Vila" sobre o que deveria ser cobrado como dívidas particulares e dívidas reais. ${ }^{73}$ Mais uma vez notamos o protagonismo das instituições camarárias e a importância de seu aval para alguns conflitos estabelecidos.

No ano de 1725 era nomeado o substituto de José de Souza Valdes para a ouvidoria da Comarca do Rio das Velhas, Matias Pereira de Sousa.

Nesse mesmo ano, D. Lourenço de Almeida escrevia ao Reino dando conta de "como os povos de todas estas Minas se acham naquele grande sossego e suma obediência em que sempre os tiveram", ao contrário do que se comentava no Reino. Afirmava que "todas as notícias que se derem em Lisboa contra estas que eu dou são fabricadas na mesma Corte". Portanto, o governador se defendia de algumas notícias que corriam de que seu governo estava enfrentando "levantamentos nas Minas". ${ }^{74}$

José de Souza Valdes ficará por pouco tempo nas Minas após o fim de seu período como ouvidor. É bem provável também que, a despeito das denúncias intentadas, seus serviços nas distantes paragens 
foram considerados relevantes pelo Reino, pois em 1726 recebia padrão de $48 \$ 000$ de tença como mercê de D. João $\mathrm{V}^{75}$

Em 21 de janeiro de 1727, Valdes requeria "a propriedade do ofício de Medidor das Jugadas do Ramo de Toes e Alviela que vagou por falecimento de Antônio de Souza (...)”. O monarca resolvia a seu favor, concedendo-lhe a dita propriedade do ofício, "do que foi o último proprietário o dito seu pai (...)". Fazia isso para manter a propriedade do ofício na família, posto que não parecesse que tivesse interesse em exercê-lo, já que alguns meses depois a concedia à sua irmã, Dona Francisca de Souza, "para o ter a pessoa que com ela se casasse (...)". ${ }^{76}$

D. Lourenço de Almeida tentara apaziguar as denúncias feitas contra sua administração. Porém, antes de findar seu governo nas Minas, viu-se envolvido em outro conflito com o então ouvidor do Sabará, Diogo Cotrim de Souza. É a historiadora Adriana Romeiro que traça uma análise do ocorrido em Minas em março de 1731. O dito ouvidor descobriu e invadiu a fortaleza da serra de Paraopeba, "onde Inácio de Souza Ferreira havia erigido uma fábrica de barras e moedas falsas, com o objetivo de fraudar a Fazenda Real, cunhando ouro sem o pagamento do quinto". As denúncias apontavam para a complacência do governador com o fato, já que o denunciante, Francisco Borges de Carvalho, relata ao ouvidor que não o havia feito antes por temer pela sua vida, já que tinha conhecimento da "boa vontade" que D. Lourenço de Almeida tinha com o denunciado. Ao saber da investida, que o ouvidor preparava em segredo, tratou imediatamente, como de costume, de escrever ao monarca relatando as suspeitas e informando-lhe que estava a par de tudo que ocorrera, elogiando inclusive a atuação do ouvidor. ${ }^{77}$

Como tivemos a oportunidade de perceber, D. Lourenço de Almeida possuía uma boa retórica e isso pareceu ser o seu trunfo na idealização de um imaginário para o seu governo nas Minas. Desse modo, suas correspondências para o Reino pareciam colaborar sempre para a imagem de uma terra que estava sempre em harmonia e tudo o que dissessem ao contrário soaria como calúnia. Adriana Romeiro registra a infinidade de denúncias que chegavam a Lisboa contra o governador das Minas, "a maior parte delas versando sobre a intromissão ilícita do governador nos negócios coloniais e as vexações que dela resultavam". Apesar disso, o governador sairia ileso de todas as acusações. O falsário foi condenado ao "degredo perpétuo às galés" e D. Lourenço de Almeida chegava a Lisboa, em 1732, após se findar seu período como governador das Minas, "envolto numa aura dourada e faustosa". Uma de suas bases de apoio nessa sociedade de Antigo Regime era uma rede muito bem articulada que conseguira traçar, envolvida que estava entre amigos e parentes ilustres, isso desde o Reino até as paragens coloniais. ${ }^{78}$

Nessa sociedade sustentada por redes clientelares e políticas que alimentavam o sistema havia lugar para todos. Diogo Cotrim de Souza foi agraciado após seu período trienal como ouvidor de Sabará e pelos serviços prestados ao Reino, "com um lugar na Casa de Suplicação em Lisboa”, cargo almejado por todos os oficiais que serviam nos lugares de Letras.

\section{Conclusão}

Os conflitos analisados aqui faziam parte do contexto político do Antigo Regime português e não afetavam a centralidade da Coroa. A estrutura político-administrativa englobava uma série de formas de governar que viabilizaram, no decorrer dos anos, a manutenção dos domínios imperiais a partir do exercício do poder em nome do monarca. As representaçôes de poder eram múltiplas, nenhuma delas negava a outra e coexistiam levando em conta principalmente as práticas cotidianas de poder. De forma mais abrangente, as diversas redes governativas que se emaranhavam por todo império garantiam o tom da política da época, articulando as inúmeras trajetórias político-administrativas desses oficiais régios.

Como foi aqui discutido, ${ }^{79}$ a Coroa se valia dos espaços que concedia a esses oficiais como forma de manutenção do poder por todo império, abrindo mão de uma centralização (que de todo modo seria inviável) para manter seus domínios. Assim, os conflitos que existiam eram frutos da dinâmica política que comportava todas aquelas formas de governar e não implicavam anomalias do sistema político. 
Práticas políticas de Antigo Regime: redes governativas e centralidade régia na Capitania de Minas Gerais (I720-I725) Claudia Cristina Azeredo Atallah

\section{Notas}

${ }^{1}$ Xavier, Ângela Barreto e Hespanha, António Manuel. As redes clientelares. In: HESPANHA, A. (coord.). História de Portugal v. 4. Lisboa: Estampa, 1994, p. 381-393 e ATALLAH, Claudia Cristina Azeredo. Uma discussão acerca do poder no Antigo Regime. In: CORREA, Helidacy Maria Muniz e ATALLAH, Claudia C. A. (Orgs.) Estratégias de poder na América portuguesa: dimensões da cultura política. Niterói: PPGH-UFF/São Luis: UEMA/Imperatriz, MA: Ética, 2010. 41-61.

${ }^{2}$ Agradeço ao professor Nuno Camarinhas por algumas dessas valiosas indicaçōes, principalmente pelas informaçōes acerca do Memorial de Ministros, "uma obra do Mosteiro de Alcobaça, feita ao longo do século XVIII, sobretudo pela mão de um Frei Luis de São Bento (mas continuada e acrescentada por outro monge, Fr. António Soares), que elege como objeto os magistrados da Coroa, desde os primeiros tempos da monarquia”, objeto de suas pesquisas. O historiador prepara agora uma edição comentada da obra.

${ }^{3}$ Posse do Governador Dom Lourenço de Almeida. Secretaria de Governo da Capitania de Minas Gerais, SC, Códice 23. APM.

${ }^{4}$ Sobre o contrato das carnes não serem convenientes nestas Minas. Secretaria de Governo da Capitania de Minas Gerais, SC, Códice 23. APM.

${ }^{5}$ Idem.

${ }^{6}$ COELHO, J. J. Teixeira. Instrução Para o Governo da Capitania de Minas Geraes 1782. Organização Caio Boschi. BH: Secretaria de Estado de Cultura, APM, IHGB, 2007. Ps. 314 e 315.

${ }^{7}$ FURTADO, Júnia Ferreira. Homens de negócio a interiorização da metrópole e do comércio nas minas setecentistas. $2^{\mathrm{a}}$ edição. São Paulo: Hucitec, 2006. Ps. 203 e 209; ROMEIRO, Adriana. Paulistas e Emboabas no coração das Minas Idéias, práticas políticas e imaginário político no século XVIII. Humanitas. Belo Horizonte: Editora da UFMG, 2008, p. 139 e 140.

${ }^{8}$ Sobre a passagem do Rio das Velhas que arrematou o Dr. José de Sousa Valdes e Sobre o contrato de carnes não serem convenientes nestas Minas." Secretaria de Governo da Capitania de Minas Gerais, SC, Códice 23. APM.

${ }^{9}$ Sobre o novo regimento dos oficiais. Secretaria de Governo da Capitania de Minas Gerais, SC, Códice 23. APM.

${ }^{10}$ Sobre o regimento dos salários e não ser observado pelo ouvidor do Rio das Velhas e muitas outras cousas contra esse ministro. Secretaria de Governo da Capitania de Minas Gerais, SC, Códice 23. APM. Grifo nosso.

${ }^{11}$ Consta nas Ordenaçôes Filipinas que a pena para os oficiais que levassem mais rendimentos do que determinasse o regimento seria a de degredo e o lugar a ser determinado para o cumprimento da pena dependeria da quantia que fosse desviada "e em todos os casos sobreditos perderão os oficios, para nunca mais os haverem, e mais pagarão anoveado tudo que levarem mais do ordenado (...)". In: Da pena, que haverão os Officieis, que levam mais do seu conteúdo em seu Regimento, e os que não tiverem Regimento o peção" Código Filipino ou Ordenaçôes e Leis do Reino de Portugal. Livro Quinto. Tit. LXXII Edições do Senado Federal: Brasília, 2004

12 "Sobre o regimento dos salários e não ser observado pelo ouvidor do Rio das Velhas e muitas outras cousas contra esse ministro". Op. cit.

${ }^{13}$ GOUVÊA, Maria de Fátima S. Redes Governativas e Centralidades Régias no Mundo Português, c.a. 1680 a $1730.0 p$. cit. p. 181.

${ }^{14}$ Sobre o Regimento dos salários que devem levar os ministros e oficiais de justiça. Secretaria de Governo da Capitania de Minas Gerais, SC, Códice 23. APM.

${ }^{15}$ Silva, Paulo Pitaluga Costa e. As Câmaras de Vereadores no século XVIII. Rio de Janeiro: Real Gabinete Português de Leitura, 2000. p. 27.

${ }^{16}$ Sobre a Vila do Papagaio. Secretaria de Governo da Capitania de Minas Gerais, SC, Códice 23. APM.

${ }^{17}$ Não há referência a respeito de algum oficial que tenha sido "castigado" pelo excesso na cobrança dos emolumentos. Isso corrobora mais uma vez o caráter de negociação que marcou o período joanino no lidar com seus oficiais.

${ }^{18}$ Secretaria de Governo da Capitania de Minas Gerais, SC, Códice 17. APM.

${ }^{19}$ COELHO, J. J. Teixeira. Instrução Para o Governo da Capitania de Minas Geraes 1782. Op. cit. p. 241.

${ }^{20}$ Falamos aqui da Revolta de Vila Rica de 170. Para tal ver: MATHIAS, Carlos Leonardo. Jogos de interesses e redes clientelares na revolta mineira de Vila Rica (c. 1709-c. 1736. Dissertação de mestrado. Rio de Janeiro: UFRJ, PPGHIS, 2005.

${ }^{21}$ Secretaria de Governo da Capitania de Minas Gerais, SC, Códice 17. APM. Infelizmente não nos foi possível ter acesso à documentação da Câmara de Sabará relativa ao período existente no APM. Os referidos documentos estavam em processo de restauro.

22 Sobre a conta a conta de Manoel Gonçalves Loures, Tesoureiro dos Defuntos e Ausentes na Comarca do Rio das Velhas / Sobre a Junta da Fazenda que se fez e a forma em que o governador deve proceder a respeito dos ouvidores que lhe desobedecem. Secretaria de Governo da Capitania de Minas Gerais, SC, Códice 23. APM. 
${ }^{23}$ Sobre a conta a conta de Manoel Gonçalves Loures, Tesoureiro dos Defuntos e Ausentes na Comarca do Rio das Velhas / Sobre a Junta da Fazenda que se fez e a forma em que o governador deve proceder a respeito dos ouvidores que lhe desobedecem. Op. cit.

${ }^{24}$ GOUVÊA, Maria de Fátima S. Redes Governativas e Centralidades Régias no Mundo Português, c.a. 1680 a $1730.0 p$. cit. p. 14,26 e 27.

25 Idem.

${ }^{26}$ Sobre a conta a conta de Manoel Gonçalves Loures, Tesoureiro dos Defuntos e Ausentes na Comarca do Rio das Velhas / Sobre a Junta da Fazenda que se fez e a forma em que o governador deve proceder a respeito dos ouvidores que lhe desobedecem. Op. cit. A Junta da Fazenda "era administrada, segundo os regimentos, pelo provedor de Vila Rica e seu escrivão, sendo ouvido o procurador da mesma Fazenda, e concorrendo o governador com a sua presença nos atos de rematações e em todos os mais do Juízo Voluntário." COELHO, J. J. Teixeira. Instrução Para o Governo da Capitania de Minas Geraes 1782. Op. cit. p. 213. Portanto, a despeito dos regimentos, a junta convocada por D. Lourenço contava também com a participação do Superintendente Geral das Casas da Moeda e Quintos, Eugênio Freire de Andrada.

${ }^{27}$ SILVA, Maria Beatriz Nizza. D. João V e a cobrança dos quintos do ouro em Minas Gerais. In: Atas do Congresso Internacional "Espaço Atlântico de Antigo Regime: poderes e sociedades". Lisboa, 2 a 5 de novembro de 2005, FCSH/UNL. Disponível em <http://cvc.instituto-camoes.pt/index.php?option=com_docman\&task=cat_view\&gid=76\&Itemid=69>

${ }^{28}$ Secretaria de Governo da Capitania de Minas Gerais, SC, Códice 23. APM.

${ }^{29}$ Sobre a criação dos ofícios de Juizes dos Órfãos. Secretaria de Governo da Capitania de Minas Gerais, SC, Códice 23. APM.

30 Sobre se não dever criar o ofício de Juiz dos Órfãos de Vila Nova da Rainha e ser suspensa a pessoa que o servia. Secretaria de Governo da Capitania de Minas Gerais, SC, Códice 23. APM.

${ }^{31}$ GOUVÊA, Maria de Fátima S. Redes Governativas e Centralidades Régias no Mundo Português, c.a. 1680 a $1730.0 p$. cit. p. 29.

${ }^{32}$ Idem. p. 30.

33 Sobre os sucessos de Vila Real do Sabará entre o Ouvidor Atual, José de Souza Valdes, que intentaram matar, e a expulsão de Bernardo Pereira Gusmão - seu inimigo e negócio de Manuel Gonçalves Loures. Secretaria de Governo da Capitania de Minas Gerais, SC, Códice 23. APM.

${ }^{34}$ AHU/MG, caixa 2, doc. 18. SALGADO, Graça (coord.) Fiscais e Meirinhos a administração no Brasil colonial. $2^{\text {a }}$ edição. Rio de Janeiro: Nova Fronteira: 1985. p. 89.

${ }^{35}$ Para José de Souza Valdes. Secretaria de Governo da Capitania de Minas Gerais, SC, Códice 17. APM.

${ }^{36}$ Carta do Doutor José de Souza Valdes. Secretaria de Governo da Capitania de Minas Gerais, SC, Códice 17. APM.

${ }^{37}$ Resposta do Excelentíssimo Senhor General para o dito Ouvidor e Representação do Superintendente Eugênio Freire de Andrade. Secretaria de Governo da Capitania de Minas Gerais, SC, Códices 17 e 21. APM.

${ }^{38}$ Para José de Souza Valdes Ouvidor da Comarca do Rio das Velhas. Secretaria de Governo da Capitania de Minas Gerais, SC, Códice 21. APM.

${ }^{39}$ SALGADO, Graça (coord.) Fiscais e Meirinhos a administração no Brasil colonial. Op. Cit p. 66 e RUSSEL-WOOD, A. J. R. Governantes e Agentes. In: BETHENCOURT, Francisco e CHAUDHURI. História da Expansão Portuguesa. Navarra: Círculo de Leitores, 1998. p. 178.

${ }^{40}$ FRAGOSO, João. A formação da elite colonial no Rio de Janeiro e de sua primeira elite senhorial (séculos XVI e XVIII). In: FRAGOSO, João; BICALHO, Maria Fernanda e GOUVÊA, Maria de Fátima (orgs.). O Antigo Regime nos Trópicos a dinâmica imperial portuguesa (séculos XVI-XVIII). RJ: Civilização Brasileira, 2001.

${ }^{41}$ Para José de Souza Valdes Ouvidor da Comarca do Rio das Velhas. Secretaria de Governo da Capitania de Minas Gerais, SC, Códice 21. APM.

42 Sobre os sucessos de Vila Real do Sabará entre o Ouvidor Atual, José de Souza Valdes, que intentaram matar, e a expulsão de Bernardo Pereira Gusmão - seu inimigo e negócio de Manuel Gonçalves Loures. Secretaria de Governo da Capitania de Minas Gerais, SC, Códice 23. APM.

${ }^{43}$ Idem.

${ }^{44}$ Ibidem.

${ }^{45}$ Sobre os sucessos de Vila Real do Sabará entre o Ouvidor Atual, José de Souza Valdes, que intentaram matar, e a expulsão de Bernardo Pereira Gusmão - seu inimigo e negócio de Manuel Gonçalves Loures. Secretaria de Governo da Capitania de Minas Gerais, SC, Códice 23. APM.

${ }^{46}$ Idem.

${ }^{47}$ Oportuno seria lembrarmos também que as Ordenaçôes Filipinas previam como crime de Lesa Majestade de Segunda Cabeça a insubordinação de um oficial da justiça que "por alguma razão cessasse seu ofício, e El-Rey mandasse lá outro Oficial novo com suas Cartas e poderes suficientes" e o primeiro "lhe não quisesse obedecer." Portanto, a despeito das Ordena- 
çôes, tais conflitos eram comuns por todo império. Código Filipino ou Ordenaçôes e Leis do Reino de Portugal. Op. cit. respectivamente, Livro Quarto, Título XIV e Livro Quinto, Título 6. p.

${ }^{48}$ HESPANHA, Antònio Manuel. A Punição e a Graça. In: História de Portugal. MATTOSO, José (dir.). Quarto Volume, O Antigo Regime (1620-1807). HESPANHA, António Manuel (coord.). Círculo de Leitores, 1993. p. 239-256. p. 239.

${ }^{49}$ Livro de Registro Geral das Mercês. D. João V. Livro 45, folha 272 e Livro 69, folha 220. ANTT. Grifo nosso.

${ }^{50}$ FRAGOSO, João; GOUVÊA, Maria de Fátima Silva e BICALHO, Maria Fernanda Baptista. Uma leitura do Brasil colonial Bases da materialidade e da governabilidade no Império. Penélope, n. 23, 2000, p. 67-88. p. 75.

${ }^{51}$ Livro de Registro Geral das Mercês. D. João V. Livros 113 e 116, folhas, respectivamente, 381 e 157. ANTT.

${ }^{52}$ AHU/MG. Cx. 4, doc. 79.

53 "Carta de José de Sousa Valdes, ouvidor-geral do Rio das Velhas, contando porque os povos de Macaúbas se levantaram (revoltaram) no ano de 1722 em virtude de um despacho de D. Lourenço de Almeida sobre uma sesmaria de José Corrêa (Correia) de Miranda." AHU, cx. 5, doc. 28, 12/06/1724.

${ }^{54}$ Carta de José de Sousa Valdes, ouvidor-geral do Rio das Velhas, contando porque os povos de Macaúbas se levantaram (revoltaram) no ano de 1722 em virtude de um despacho de D. Lourenço de Almeida sobre uma sesmaria de José Corrêa (Correia) de Miranda." Op. cit.

55 SUBTIL, José. Os poderes do centro. História de Portugal. MATTOSO, José (dir.). Quarto Volume, O Antigo Regime (1620-1807). HESPANHA, António Manuel (coord.). Círculo de Leitores, 1993. p. 239-256. p. 160. Outra questão importante aqui é a configuração da ideia de que, ao rigor das leis opunha-se a clemência real. Esta, "estava relacionada com um dos tópicos mais comuns da legitimação do poder real - aquele que representava o príncipe como pastor e pai dos súditos, que mais se devia amar do que temer. “(...) estabelecia-se como regra de ouro que, ainda mais frequentemente do que punir, devia o rei ignorar e perdoar, (...), não seguindo pontualmente o rigor do direito (...).”HESPANHA, Antònio Manuel. A Punição e a Graça. Op. cit. p. 247.

${ }^{56}$ Ainda vale à pena lembrar que, segundo as Ordenaçôes, questôes relacionadas à graça e mercê "sejam seladas com cada um de nossos selos e passem por nossa Chancelaria”. Código Filipino ou Ordenaçôes e Leis do Reino de Portugal. Op. cit. Livro Segundo Título XXXIX p. 404.

${ }^{57}$ Ferreira, Francisco Ignácio. Opulência de Minas Gerais. RAPM, Ano 20, 1924. p. 22 e Cartas de Sesmarias. RAPM, Belo Horizonte, volume 4, ano 1899. p. 176.

${ }^{58}$ AHU/MG. Cx. 5, doc. 29.

${ }^{59}$ AHU/MG. Cx. 5, doc. 29.

60 "Sobre extinguir o ofício de solicitador da fazenda Real" Secretaria de Governo da Capitania de Minas Gerais, SC, Códice 23. APM.

${ }^{61}$ Idem.

62 "Sobre a nova criação de alguns oficiais da Fazenda". Transcrição do códice colonial. v. 1. Op. cit.

${ }^{63}$ Idem. Aqui mais uma vez se subentende uma acusação contra o ouvidor José de Souza Valdez, já que Sabará era sede administrativa da Comarca do Rio das Velhas e o dito ouvidor também assumia o cargo de provedor.

${ }^{64}$ AHU/MG. Cx. 5, doc. 29.

${ }^{65}$ Registro Geral das Mercês de D. João V, Livro 21, folha 212. ANTT.

${ }^{66}$ Registro Geral das Mercês de D. João V, Livro 21, folha 212. ANTT.

${ }^{67}$ HESPANHA, António Manuel. Depois do Leviathan. In: Almanack brasiliense, número 5, maio/2007. Disponível em $<$ www.almanack.usp.br>

${ }^{68}$ AHU/MG. Cx. 5, doc. 116.

${ }^{69}$ AHU/MG. Cx. 6, doc. 24.

${ }^{70}$ AHU/MG. Cx 6, doc. 26. Tal conflito parece ter suscitado ao Provedor da Fazenda, António Berquó Del Ryo, a reclamação sobre os espaços de jurisdição que citamos acima.

${ }^{71}$ Código Filipino ou Ordenaçôes e Leis do Reino de Portugal. Op. cit. Livro Primeiro, T

${ }^{72}$ AHU/MG. Cx 6, doc. 26.

${ }^{73}$ AHU/MG, Cx. 6, doc. 30.

${ }^{74}$ AHU/MG. Cx 6, doc. 46.

${ }^{75}$ Registro Geral das Mercês de D. João V, Livro 71, folha 114. Agradeço ao professor Nuno Camarinhas pela indicação dessa referência.

${ }^{76}$ Registro Geral das Mercês de D. João V, Livro 18 folha 122 e 122v. ANTT. 
${ }_{77}$ ROMEIRO, Adriana. Confissóes de um falsário: as relaçōes perigosas de um governador nas Minas. Anais do XX Simpósio as Associação Nacional da História, Florianópolis, 1999. p. 321-337.

${ }^{78}$ Idem.

${ }^{79}$ Esse artigo é parte integrante da tese de doutorado de ATALLAH, Claudia Cristina Azeredo. Da justiça em nome d'El Rey: Ouvidores e Inconfidência na capitania de Minas Gerais (Sabará, 1720-1777). Tese de Doutorado apresentada ao Programa de Pós-Graduação em História Social da UFF, Niterói, 2010. Agradeço a CAPES pelo financiamento da pesquisa no Arquivo Nacional da Torre do Tombo em Lisboa durante o período compreendido entre setembro/dezembro de 2009.

\section{Referências bibliográficas}

ATALLAH, Claudia Cristina Azeredo. Da justiça em nome d'El Rey: ouvidores e Inconfidência na capitania de Minas Gerais (Sabará, 1720-1777). Tese de Doutorado apresentada ao Programa de Pós-Graduação em História Social da UFF, Niterói, 2010.

. Uma discussão acerca do poder no Antigo Regime. In: CORRÊA, Helidacy Maria Muniz e ATALLAH, Claudia C. A. (Orgs.). Estratégias de poder na América portuguesa: dimensóes da cultura política. Niterói: PPGH UFF/São Luis: UEMA/Imperatriz, MA: Ética, 2010.

FRAGOSO, João. A formação da elite colonial no Rio de Janeiro e de sua primeira elite senhorial (séculos XVI e XVIII). In: FRAGOSO, João; BICALHO, Maria Fernanda e GOUVÊA, Maria de Fátima (Orgs.). O Antigo Regime nos Trópicos a dinâmica imperial portuguesa (séculos XVI-XVIII). Rio de Janeiro: Civilização Brasileira, 2001. p. 29-71.

FRAGOSO, João; GOUVÊA, Maria de Fátima Silva e BICALHO, Maria Fernanda Baptista. Uma leitura do Brasil colonial. Bases da materialidade e da governabilidade no Império. In: Penélope, n. 23, p. 67-88, 2000.

FURTADO, Júnia Ferreira. Homens de negócio a interiorização da metrópole e do comércio nas minas setecentistas. $2^{a}$ edição. São Paulo: Hucitec, 2006.

GOUVÊA, Maria de Fátima S. Redes Governativas e Centralidades Régias no Mundo Português, c.a. 1680 a 1730. In: GOUVÊA, Maria de Fátima S. e FRAGOSO, J. L. R. (Orgs.). Na Trama das Redes. Politica e Negócios no Império Português sécs. XVI-XIX. Rio de Janeiro: Civilização Brasileira 2010.

HESPANHA, Antònio Manuel. A punição e a graça. In: MATTOSO, José (dir.). História de Portugal. Quarto Volume, O Antigo Regime (1620-1807). Lisboa: Círculo de Leitores, 1993.

MATHIAS, Carlos Leonardo. Jogos de interesses e redes clientelares na revolta mineira de Vila Rica (c. 1709-c. 1736). Dissertação de mestrado apresentada ao Programa de Pós-graduação em História Social da UFRJ, Rio de Janeiro, 2005.

ROMEIRO, Adriana. Confissões de um falsário: as relaçôes perigosas de um governador nas Minas. In: Anais do XX Simpósio as Associação Nacional da História, Florianópolis, 1999.

Paulistas e Emboabas no coração das Minas Idéias, práticas políticas e imaginário político no século XVIII. Humanitas. Belo Horizonte: Editora da UFMG, 2008.

SILVA, Paulo Pitaluga Costa e. As Câmaras de Vereadores no século XVIII. Rio de Janeiro: Real Gabinete Português de Leitura, 2000.

RUSSEL-WOOD, A. J. R. Governantes e agentes. In: BETHENCOURT, Francisco e CHAUDHURI. História da Expansão Portuguesa. Navarra: Círculo de Leitores, 1998.

SALGADO, Graça (Coord.). Fiscais e meirinhos: a administração no Brasil colonial. 2a edição. Rio de Janeiro: Nova Fronteira: 1985.

SILVA, Maria Beatriz Nizza. D. João V e a cobrança dos quintos do ouro em Minas Gerais. In: Atas do Congresso Internacional "Espaço Atlântico de Antigo Regime: poderes e sociedades". Lisboa, 2 a 5 de novembro de 2005, FCSH/UNL. Disponível em <http://crc.instituto-camoes.pt/index.php?option=com_docman\&task=cat_ view\&gid=76\&Itemid=69>

SUBTIL, José. Os poderes do centro. In: MATTOSO, José (dir.) História de Portugal. Quarto Volume, O Antigo Regime (1620-1807). Lisboa: Círculo de Leitores, 1993.

XAVIER, Ângela Barreto e HESPANHA, António Manuel. As redes clientelares. In: MATTOSO, José (dir.) História de Portugal. Quarto Volume, O Antigo Regime (1620-1807). Lisboa: Círculo de Leitores, 1993. 
Práticas políticas de Antigo Regime: redes governativas e centralidade régia na Capitania de Minas Gerais (I720-I725)

Claudia Cristina Azeredo Atallah

\title{
RESUMO
}

Pretende-se, neste artigo, propor um estudo dos conflitos entre o governador da Capitania de Minas Gerais (1721-1732), Dom Lourenço de Almeida, e o ouvidor da Comarca de Sabará (1720-1725), José de Souza Valdes, considerando o período compreendido entre 1720 e 1725. Tomamos como referência para esta análise o estudo das redes clientelares e politicas, concedendo atenção especial ao conceito de redes governativas desenvolvido pela historiadora Maria de Fátima Gouvêa. Acreditamos ser possivel identificar, a partir daí, algumas práticas políticas inerentes à sociedade de Antigo Regime em Portugal e seus dominios, bem como as relaçôes estabelecidas entre as redes locais nas Minas e o Reino.

Palavras-chave: Minas Gerais, Antigo Regime, redes governativas, politica, justiça.

\begin{abstract}
The intention of this article is to propose a study of conflicts between the governor of the Minas Gerais captaincy (1721-1732), Dom Lourenço de Almeida, and the magistrate of the Sabara County (1720-1725), José de Souza Valdes, considered the period between 1720 and 1725. We have as reference for this analysis, the study of the political and clientelist networks, giving special attention to the concept of government networks developed by the historian Maria de Fátima Gouvêa. We believe it is possible to identify, from this point, some political practices inseparable from the society of Old Regime in Portugal and its domains, just like the relations established between the local systems in Minas and the kingdom.
\end{abstract}

Keywords: Minas Gerais, Ancient Regime, government networks, politics, justice. 